\title{
'Repentant' artists in Egypt: debating gender, performing arts and religion
}

\author{
Karin van Nieuwkerk
}

Published online: 19 November 2008

(C) The Author(s) 2008. This article is published with open access at Springerlink.com

\begin{abstract}
This article explores the emergent public sphere in Egypt in the early 1990 s by analysing the debates about the 'repentant' artists. Many artists, mostly women but also a few men, stepped down from art for religious reasons. Some of them even started to preach against art because they considered their former profession haram. The 'repentance' of so many famous performers led to fierce contestations in the media. Art became an issue par excellence for debating notions of the 'common good' and the 'good Muslim.' Media were intensively used by secularists, conservative Muslims, Islamists, the regime and repentant artists to publicise their version of Islam. The different voices in the debate are analysed to investigate whether they constitute a counterpublic.
\end{abstract}

Keywords Islamic Revival · Repentance · Performing arts · Egypt · Gender

At the beginning of the 1990s, an incessant stream of 'repentant' artists $^{1}$ struck Egypt like an earthquake. In the 1980s, a few artists had seen the light and publicly announced their stepping down from art: the actress Shams al-Barudi (1982), shortly followed by her husband Hasan Yusif, the dancer Hala al-Safi (1987), the singer Shadia (1987), the actress Hana' Tharwat and her husband Muhammad al-'Arabi (1987) and singer Yasmin al-Khiyyam (1989). But from the 1990s — with a peak in 1992 - the 'caravan' of stepped-down artists increased at a staggering speed: Shahira, 'Afaf Sho 'ib and Madiha Hamdi veiled and retired, soon to be followed by Soheir al-Babli, Soheir Ramzi, Sawsan Badr, Farida Seif al-Nasr and many others. In 1992, Egypt was struck by a natural earthquake as well. Yet, to suggest any relationship between the 'repentance' of artists and the earthquake is to take part in a

\footnotetext{
${ }^{1}$ Not all artists like the label repentance. For that reason, I have used inverted commas for 'repented' artists (fannanat ta' ibat). Other notions that are used as synonyms are stepped-down artists (fannanat mu 'tazilat) or veiled artists (fannanat muhagabat).
}

K. van Nieuwkerk $(\triangle)$

Radboud University Nijmegen, Nijmegen, The Netherlands

e-mail: k.v.nieuwkerk@let.ru.nl 
heated debate about the reasons behind the stepping down of so many famous performers. The fierce disputes between secularists and Islamists about the 'repentant' artists will be central to this article.

The early 1990s, and particularly 1992, was a turbulent time in Egyptian history. Egypt was hit by a series of terrorist attacks, on Copts, policemen and foreign tourists. The writer Farag Fuda was assassinated in 1992. The regime began to hunt down 'Islamists,' 'extremists' and 'terrorists' and blurred distinctions between them. The battle between the regime and the extremists was not limited to the political and military field. In the socio-cultural sphere, confrontations were also taking place, ranging from the destruction of billboards advertising theatre plays to attacks on theatrical groups, performers and video shops (Ramzi 1994). As Zubaida noted, modern Islamism attempted to impose religious authority on culture and society, which meant a quest for 'the moralisation of the public space, the imposition of ritual observance, and the censorship of cultural and entertainment products (Zubaida 2002: 19). For the Islamic revival movement, in all its more and less militant facets, the creation of alternative Islamic forms of popular diversion and the development of forms of art and culture compatible with pious sensibilities was of crucial importance (Hirschkind 2006: 128).

Whereas the militant attacks could be discarded as 'terrorist extremism,' the general Islamic revivalist campaign for morality in society and art was less easily dismissed by opponents and the government. It is fed by a broad piety movement among the Egyptian population (Mahmood 2005). The Islamic trend was accordingly met with an ambivalent attitude by the regime. The government was trying to profile itself as more religious than the extremists (Tadros 1994). It was at the same time opposing and accommodating various strands of Islamists depending on shifting evaluations of the danger they were perceived to pose to the regime (Hirschkind 2006: 61-62). Within this tense climate, the repentance and veiling of many actresses, singers and dancers, high-profile media figures who set pious examples to their fans, proved to be a complex and sensitive issue. The repentant artists accordingly became objects of intense media debates. Conservative Muslims and Islamists capitalised on the repentance and veiling of artists to promote their views on morality in Egyptian society. Views that were contested by seculars and liberals were met with ambiguous responses by the regime.

The fierceness and multiplicity of voices in this debate can be analysed as an example of the 'emergent public sphere.' As Salvatore and Eickelman (2004) have argued, increasingly open discussions about issues related to the 'common good' are emerging in Muslim countries. Cassettes, sermons, books, including the increasing amount of religious booklets, videos, TV, radio and the Internet have led to a booming public sphere. Large numbers of people, and not just the elite, want a say in political and religious issues in the emergent public sphere. New leaders and spokespeople claim the right to speak in the political and religious arenas and disseminate their ideas through various media. The new public sphere is performative, that is, the media are not just conveying messages but are also part of the message, and participatory as well. Also, women and minorities find their way into the fields of political and religious discourse. New media seem to open possibilities for new people to express new ways of thinking (Eickelman and Anderson 1999). 
Salvatore and Eickelman (2004: xiii) note the paradox of modern Muslim societies, that although there is no singular public, but rather a multiplicity of overlapping forms of publics, the public good is increasingly defined within the parameters of Islam. For Egypt, the late preacher Sheikh al-Sha'arawi, and the 'bornagain' scholar, Mustafa Mahmud, are particularly mentioned as important figures in the trend towards 'the publicization of Islam' in the early 1990s. Their proliferation in the form of cassettes, books and particularly TV programs are key tools for gaining dominance in public debates. They also happen to be important figures related to the repentance of artists.

Yet how far do these voices constitute a counterpublic (Fraser 1990), that is, an alternative public independent of the regime? Are these new voices, using new media, actually expressing new ways of thinking? Mona Abaza (2006: p. 58) answers these questions negatively for Mustafa Mahmud as well as al-Sha arawi. She sees them as exponents of the petro-Islam and the growing Saudi-tisation of Egyptian society and as closely related to the regime. Also, Hirschkind (2006: 54) describes al-Sha arawi as the government's preacher used by the government against the more contestory parts of the Islamic movements. Sami Zubaida (2002:19) generally argues that the conservative Islamic attempts at imposing morality fit in well with the aim of authoritarian rulers. They have a common quest for 'cultural nationalism' that seeks the restoration of authenticity and the eradication of inauthentic cultures or products of 'Western corruption.' This quest reinforces social control and authoritarian rule which is much favoured by the regimes in the region.

Apparently, the emergent public sphere does not automatically lead to the proliferation of liberal and democratic voices but can lead to the spread of all kinds of voices, including conservative, antidemocratic and authoritarian voices. Yet, do these gloomy views about the emergent public sphere in Egypt of the 1990s also hold true for the repentant artists? They clearly belong to the 'new people' who find their way into the arenas of political and religious discourse, profoundly using the media. Do they put forward new ways of thinking? What ideas about the 'good Muslim' and particularly the 'good Muslim woman' do they disseminate?

In this article, I try to unravel the different tales about why artists have stepped down, including the artists' own stories. I will argue that the debates about and by the repentant artists are good examples of the emergent public sphere. First, art became an issue par excellence for debating notions of the 'common good' and the 'good Muslim'. Second, the debates on the repentant artists highlight the intense use of media. The former performers are public figures, known to millions. They are tremendously influential whether in fashion or veiling to a wide and diverse public. Because of the 'dangerous' mediatised publicisation of their version of Islam, it is fiercely countered in official media and supported in other media. Third, there is a divergence of voices consisting foremost of secularists, conservative Muslims, Islamists, the regime and repentant artists. For all the voices concerned, religion becomes the way of framing the discussions on art. Lastly, conservative voices dominate the discourses of the early nineties. Sheikh al-Sha arawi and Mustafa Mahmud are, together with conservative preacher Dr. 'Omar `Abd al-Kafi, influential figures in the repentance of artists. These conservatives are given media space by the government. Whereas the conservative voices can probably not be analysed as a counterpublic independent of the government, the case of the repentant artists is more ambiguous. 
The research of this article is based on archive material and interviews with stepped-down artists. I collected stories of 28 well-known singers, dancers, actors and actresses who stepped down and 'repented', and in some cases returned, including five men. I was able to have personal interviews with 15 of them. I also interviewed 5 unknown retired veiled female performers during fieldwork in 2005, 2006 and 2008. The research project deals with several waves of repentance, veiling and stepping down as well as the eventual return of several artists between 1980 and 2008. This paper will concentrate on the highpoint - the beginning of the 1990s when the 'caravan' of stepping down turned into a musalsa, TV series, followed by millions (Ruz al-Yusif, 11-10-1993). ${ }^{2}$

\section{First act: the veil and 'repentance' of artists}

'Your decision to step down has shaken the earth'. Thus Shahira, a former actress who stepped down and veiled in 1991, congratulated her friend 'Afaf Sho'ib (interview in Mawed, November 1992). Shahira became the unofficial spokeswoman for the repentant actresses and communicated the news to the media. 'Afaf and Shahira visited Sheikh Mitwalli al-Sha'arawi together with their friend and former singer Yasmin al-Khiyyam who retired in 1990. They also followed the religious lessons organised by Yasmin al-Khiyyam in her mosque named after her late father, Sheikh al-Hosari. In addition, they followed religious lessons given by another former actress who turned into a preacher, Hana' Tharwat. The latter retired and took the niqab in 1987. Furthermore, the lessons of Mustafa Mahmud were very popular among the growing group of stepped-down artists. The number of actresses, singers and dancers stepping down and repenting gained a critical mass in the early 1990s. They organised themselves, became more visible and triggered more and more comments.

During the interviews I conducted with 'Afaf Sho'ib in 2005, she stressed the fact that she stepped down and veiled three days before the earthquake of October 1992. Influential in her religious turning was her eldest brother's death in 1988. He phoned her at 10 o'clock in the evening and told her he anticipated his death. She did not believe him as he was healthy 'like jasmine.' At 3 o'clock, however, her other brother called and told her he had actually died. She suddenly realised the volatility of life and felt God wanted something of her. She travelled to the United States for the treatment of her sick mother and considered cosmetic surgery for herself. Her relatives discouraged her and she decided to do a isthikhara prayer, a special prayer to seek God's advice, in this case whether to do the surgery or not. She then received a vision in which her deceased brother told her that life is trivial and a huge theatre in which people cheat on each other. 'Reality starts after death in the afterlife, in paradise or hell', he warned her. She decided against the operation and returned to Egypt. More and more she felt she should withdraw from acting. She followed religious lessons and met with repentant artists. After such a meeting on Friday, she prayed, read Qur'an and opened the Qur'an three times on arbitrary pages. The

\footnotetext{
${ }^{2}$ For the first stage, see van Nieuwkerk (2008); presently I am working on the third stage in which artists have returned to the screen or stage and try to make pious productions.
} 
messages 'struck her being and quaked her soul' (interview in al-Nur, 21-10-1992). She then asked God in a supplicatory prayer to guide her in veiling. After that, she felt hypnotised and moved beyond her willpower to her cupboard and put on the hijab. 'Afaf also had several other spiritual experiences. In one of her visions, she foresaw scenes she witnessed during the earthquake a few days later. ${ }^{3}$ Such spiritual moments and visions did not only figure in 'Afaf's story but abounded in several stories of repentant artists (van Nieuwkerk 2008).

After her retirement, she dedicated her time to charity, particularly during the aftermath of the earthquake, and Islamic da'wah. She prided herself in having converted several Christians from the West and reverted many Muslims, including three female artists. She sincerely hoped I would be 'guided' as well, or at least leave her house veiled. She made considerable missionary efforts during the interview. The fact that I was not a Muslim (yet) should not impart my taking the veil. She called me later that evening to tell me that Mary/Miriam was veiled as well. It was an interesting experience to undergo the strength of her da wah. She did not label herself a preacher, but as a former actress she was used to conveying messages convincingly. Like other repentant artists, she passionately promoted veiling among all women. She did not declare the performing arts totally haram but considered it haram for women, at least according to the 1992 interview in al-Nur. During the interview with me in 2005, she had returned as a veiled actress. She explained that she was very spiritual at the time of her stepping down, and wanted to use her time in a way that directly pleased God. Besides, there were hardly any roles for veiled actresses at the time because the government banned all veils from the screen. Moreover, she was used to constantly changing her acting roles and was afraid she would stray from the right—veiled-path.

Soheir al-Babli was a comedienne and retired shortly after `Afaf Sho'ib. When I interviewed her in 2006, she had returned to acting and was in the middle of a new production. She thus discussed her reasons for returning in more detail than her former reasons for stepping down. Yet she affirmed the information from interviews in the early 1990s in general outlines. She was in a break in the performance of the play directed by the famous director, Galal Sharqawi, when she decided to quit. She related the events that led to her stepping down in a rather funny way. ${ }^{4}$ The last nine years before stepping down she went to Mecca to do the umrah with her friend, the actress Yusra. She veiled during the umrah and unveiled afterwards. If people asked her whether she 'repented' she used to laugh at them and retorted: 'Repent from what? Did you repent from watching me?'! The last year, she was tired of performing the same theatre play as the two preceding seasons. During the umrah, she did several $d u$ ' $a$ 's to ask God to provide her with a pious husband, to show her the way and to forgive her sins (see also interview in al-Musawwar, 27-8-1993). She was not used to praying regularly but now felt like praying and reading Qur'an. The people around her asked her: 'Ooh, you are not going to veil are you?' 'No, no', she replied, 'bi 'id 'anni il-hagat di”" (far from me these kind of things).

\footnotetext{
${ }^{3}$ Serial made in Saudi-Arabia on 'repentant' artists, 'Those who are guided'/'Elazee ahtado' (Sana Production Company, n.d.).

${ }^{4}$ Video recording of her talk at the 22nd Annual National Convention, Los Angelos. 'From Heart to Heart.' Around 1999.
} 
Yet six months later she veiled. She related concerning this intermediate period that she returned to her villa in Alexandria and supervised repairs being done to her house. It was done by a certain Mahmud, a pious person, who to her great astonishment did not accept ba'shish or advance payment. Mahmud and his workers prayed during work, which initially made her afraid that the sensationalist press would describe the row of praying and Islamically-dressed workers under the headline: 'a group of terrorists in Soheir al-Babli's villa'. Mahmud always averted his eyes from Soheir, a very strange experience for a famous actress, and urged her to dress up while his workers were around. She asked him about religion, started reading and slowly changed her appearance. She realised how little she knew about her religion. This situation continued until the rehearsal for the play with Galal Sharqawi started again and she had to return to Cairo. She travelled with her daughter-who veiled two years before her - and woke up for the fajr-prayer, which was very unusual for her. She did a $d u^{\prime} a$ and slept as a baby whereas she usually needed sleeping pills.

She went to a 'famous doctor', who was probably Dr. 'Omar 'Abd al-Kafi because during other interviews she named his fatwas (Ruz al-Yusif, 14-10-2005). She asked him about the permissibility of her work. He told her straight that it was haram. She replied: 'thank you' and returned home (interview in Tawabon, 26-112005). While waiting for someone to bring her the script, she asked her daughter to give her a veil. She felt the theatre was like a devil pulling her towards him. She restlessly put the tarha on and watched herself in the mirror without make up and with a veil. She then phoned Shahira, who usually conveyed the news of the repentance of artists to the media, and asked to make her veiling public. The publicisation of her veiling would prevent her relapsing into the old pattern. She broke the contract with Galal Sharqawi and gave him the money back. In the end, she married Mahmud and had her honeymoon in Mecca and Medina. She opened a business in Islamic fashion and ten years later returned as a veiled actress.

Soheir al-Babli quit the play titled 'Atiyya, the terrorist', a play Galal Sharqawi had just rewritten to include hints of the terrorist attacks at that time. With so many artists stepping down and Soheir al-Babli on top of that, a limit was reached. When the play resumed its second season, with Galal's daughter 'Abir Sharqawi as the leading actress, the cream of the artists' world showed up. They wanted to demonstrate their support for the play and their dismay at the 'fundamentalist turn' of so many artists (Brooks 1998: 241-242).

\section{Second act: earthquake and payment}

The secular press and general public responded to the growing amount of repentant artists in several ways. Firstly, the general public and adversaries reacted with jokes, pestering and debunking remarks. Cynical jokes like the following were told among the Egyptian populace: 'Who are the second best paid women in Egypt? Belly dancers of course, because Saudi tourists throw banknotes of hundred dollars at their feet while they are dancing. Who are the best-paid women in Egypt? The converted belly dancers of course, because Saudi sheikhs transfer banknotes of thousand dollars to their accounts if they stop dancing' (Brooks 1998: 242). The repentant artists were accused 
of being only interested in money, before and after 'conversion'. It was added that the repentant stars were anyhow becoming older and that this was the way to make a last big haul (Brooks 1998: 242-243). Shams al-Barudi was faced with repeated showings of her old seductive films, particularly the film produced in 1973 by Abu Saif 'Hamam al-Malitili' (The Malatili Bath) in which she appeared in a bathing suit. The films were said to be a greater success than at the time of their first release $(R u z$ al-Yusif, 7-3-1988). The movie critic, Kamal Ramzi (1994), wrote that it was easy to explain the phenomenon of retirement. Hala al-Safi had turned from a quick moving dancer into a heavy and slow performer, and her colleague Sahar Hamdi had ever mounting problems with the vice police. Soheir al-Babli should have retired long ago as she was approaching sixty. The journalist Ibrahim 'Issa (1993: 86-90) commented on the stepping down of Shams al-Barudi, Hana' Tharwat, Nisrin, Shahira and Soheir Ramzi that they were mediocre actresses anyhow and that no one would miss them. He suggested that stepping down was an ingenious way to remain in the spotlights despite lack of success as an actress. These reactions confirmed the general image of artists as greedy for money and attention. The adversaries stressed the artists' material desires and bypassed their spiritual accounts.

A second reaction by journalists, commentators and performing artists emphasised the personal circumstances and the earthquake as reasons behind their repentance. The religious turn of Hala Fou ad, Shahira and Shadia was related to their illnesses. The authors of Repentant Artists and the Sex Stars, who were sympathetic to the repentance of artists, claimed that they were even offered money in case they would write that veiling and stepping down by artists was only due to illness (Nasif and Khodayr 1993: 170). Opponents related the repentance of 'Afaf Sho 'ib, Soheir al-Babli, Sahar Hamdi, Farida Seif al-Nasr and Soheir Ramzi to the earthquake and the fear of the Day of Judgement. The Islamist protagonists reacted angrily to this allegation because they interpreted this reasoning as 'diminishing the greatness of God's Guidance' (Kamil 1993: 23). Most actresses I interviewed who stepped down shortly after the earthquake denied any connection between the two phenomena. 'Afaf Sho'ib, however, connected the earthquake with repentance in the case of all other actresses except for herself. She stepped down three days before the earthquake, a fact she repeatedly stressed. She interpreted this as personal guidance by God, unlike the more general 'wrath of God and His call upon mankind to repent', the significance many people attached to the earthquake. Only one former folklore dancer I interviewed said that the earthquake was the main reason to stop. She was scared to death by the earthquake and felt it was God's punishment. She perceived her work as haram and immediately quit and veiled after the earthquake. She expressed her gratitude to be 'guided' by God: she had not died as a sinful dancer but received a chance to start a brand new life.

In these debates and reactions, the repentant artists were neither blamed, criticised nor ridiculed but their stories were treated as personal matters. The details of their visions might be questioned as very coincidental, but generally the personal freedom of anyone was stressed to either step down or veil or to keep on working. Several performing artists I interviewed took this approach. What they detested, however, was the label repentant artist. By using the term 'repentance', a general claim was made that art is haram. This position was unacceptable to those working in the art scene. If there was a reason to repent it might be because some of these actresses, 
singers and dancers lived a dissolute life and not because working in the field of art in itself made repentance necessary (Nasif and Khodayr 1993: 131-144).

In a third response, several opponents drew attention to the dangerous political and religious aspects of the phenomenon of the veiled actresses. A straightforward connection was made between extremism or fundamentalism and the repentant artists. Two different relations between the phenomenon and fundamentalism were postulated: fear of extremist attacks and payment to veil and step down. At the beginning of the $1990 \mathrm{~s}$, a number of intellectuals and journalists were attacked, and artists could be the next targets. The singer Yasmin al-Khiyyam, daughter of the famous Qur`an reciter Sheikh al-Hosari, was threatened. Extremists urged her father to pray in front of the ka $b a$ and ask God to take away his daughter; or at least her voice. They also threatened to throw acid in her face (Nasif and Khodayr 1993: 98). Farida Seif al-Nasr-who retreated and later returned to show business - was attacked upon her return (Ruz al-Yusif, 2-8-1993). Hala al-Safi recounted a dream in which she passed a mosque and was frightened because she was not properly dressed. Suddenly a man, who was later identified as the Prophet, appeared in her dream and covered her. The psychiatrist, novelist and feminist, Nawal al-Sa'adawi, concluded that one need not be a psychiatrist to interpret this dream as a reaction against pressure by religious extremists (Brooks 1998: 244).

Yet the most common and enduring accusation or rumour was the payment of artists to step down and veil. It was already rumoured in the late 1980s that groups paid artists if they veiled and stepped down. I remember Nadia, a dancer whom I met in 1987 in the Cairene street of popular artists, Muhammad 'Ali Street. She was originally from Alexandria and divorced twice. In order to provide for her kids, whom she left with her mother in Alexandria, she worked at weddings and in cheaper nightclubs. Nadia heard the rumours of payment and was eagerly awaiting the offer of 'repentance in exchange for money'. Unfortunately, she could not find those groups and had to keep on working. In the early 1990s, the rumours were strengthened by TV presenters and actresses who maintained that they were actually offered money to step down; an offer which they, of course, refused. Fatin Hamama and Nagwa Ibrahim claimed payment as well as Elham Shahin (Ruz al-Yusif, 11-101993). Fatin Hamama was allegedly offered 7 million pounds (Kamil 1993: 21). Nagwa Ibrahim claimed she would receive 1 million dollars and a monthly salary of 150,000 dollars (idem: 31). Elham Shahin said she received a phone call that informed her that she would be paid a million dollars for stepping down and veiling. This rich person had his channels through the repentant artists as well as journalists from the religious press to check her actual veiling and stepping down. The payment was scaled according to talents and stardom, and only Elham, Yusra and Lela 'Ilwa would receive a million dollars. This might explain the bad luck of Muhammed 'Ali Street dancer Nadia. There was also the case of an Egyptian art director, making the accusations more complex. He recorded his story of repentance on five tapes and turned into a preacher against art. He was later 'disguised' as a failed student and a tool at the hand of 'professional traders of extremism' who paid Egyptian actresses to 'finish' them (Ramzi 1994). These rumours and accusations were very difficult to ascertain and were denied by the stepped-down actresses.

More subtle accusations by journalists of payments were the allegations of rich oil sheikhs marrying the Egyptian actresses. The sheikhs allegedly forced them to veil 
and to step down from acting and then shortly after divorced them in order to marry the next actress. Money invested by a Saudi company in order to produce a videocassette about the repentance of artists was said to be used to spread the Wahhabi version of Islam throughout the Middle East ('Issa 1993: 35). Shams alBarudi allegedly received financial assistance to buy her old seductive films in order to take them out of circulation. Soheir Ramzi and Shams al-Barudi were invited to tell their stories of guidance in Jeddah and were said to be amply remunerated (Ruz al-Yusif, 3-5-1993). The veiled artists were accused of being actively used by outside forces, to wit Saudi Arabia, to spread their 'Bedouin, desert version of Islam' ('Issa 1993: 77-79).

Particularly in the book al-Harb bi al-Niqab, the last-mentioned author made a strong argument to analyse the emergent hijab and niqab phenomenon among Egyptian women as a Saudi-tisation of Egypt. The migration of many Egyptians and their yearlong submergence in the Saudi way of life and thinking made many Egyptians susceptible to Salafi extremism. Saudi-influenced preachers such as Sheikh Mitwalli al-Sha arawi and Dr. 'Omar 'Abd al-Kafi, the two sheikhs most influential on repentant artists, rose to stardom through their mediatised appearances and their connections with artists. Their influence on artists catapulted their own fame and spread their Salafi ideology, according to Ibrahim 'Issa. The same author also launched a massive anti-Dr. 'Omar 'Abd al-Kafi campaign in the weekly magazine Ruz al-Yusif in 1993. He argued that the preaching of Sheikh al-Sha arawi and Dr. 'Omar 'Abd al-Kafi was destroying the Egyptian art production- the basis of Egypt's central position in the region and an important source of income. Besides, he accused them of preaching against the freedom of women ('Issa 1993: 77-79). He feared the fundamentalist or Saudi campaigns to veil artists and let them stay at home was a way of sending women back to 'ages of oppression'.

The secularist discourse against the repentant artists invoked nationalist deliberations. Egypt and its national heritage should be safeguarded from foreign or false influences. The cultural nationalist discourse put forward by Ibrahim 'Issa and others warned against the inauthenticity of 'petro-dollar' preachers and the veiled artists. They pointed to the danger of the Saudi-tisation of Egypt and the loss of the cornerstones of Egypt's civilization, particularly its art. Cultural and national identities are often expressed through gender symbolism. The call upon female performers to veil and return to the house were thus not only seen as inauthentic ideas on art and religion but also on gender. The ideas on art and gender promoted by means of Egyptian penitents themselves were seen as particularly powerful tools in the Saudi-tisation of Egypt. They were not only perceived as pawns of extremist Islamists but also as active missionaries of fundamentalist discourses on gender and art.

\section{Third act: the Islamist press strikes back}

The Islamist press came to the aid of the veiled actresses. This was partly due to the ex-performers themselves. They chose the Islamist press to tell their stories. Shams al-Barudi narrated 'her journey from darkness to the light' to the Islamic newspaper al-Nur (10-2-1988). Also, 'Afaf Sho ib preferred to tell her story to al-Nur because she trusted this Islamic magazine (12-10-1992). This did not necessarily mean 
though that the way they were portrayed in the Islamist booklets bore the approval of all veiled artists. The Islamist press consistently depicted the artists as sinners who returned to 'the right fold'. It attached the strong label of repentance to the veiled actresses, a label disliked by some of them. The Islamist authors enforced the idea of artists as sinners and non-believers as opposed to repentant artists who saw the light and became true believers. Not all stepped-down artists were comfortable with such a mono-dimensional view of their life stories.

The Islamist press warmly embraced and circulated the stories of the repentant artists. They promoted the genre of the repentance literature, a genre that thrived in the early 1990s. The proliferation of booklets with such titles as The tears of the penitents was probably related to the earthquake because this was perceived to have awakened people's awareness of God's wrath. The ex-performers' narratives were sources of inspiration for other sinners' stories of remorse and became like a script. I collected several booklets in which the stories of artists are reprinted. Some books are exclusively focussed on artists, in others their stories are printed amidst those of diverse 'repentant sinners' such as burglars, and even with narratives of Western converts. The mixture is interesting because it equals the guidance of a Muslim sinner to that of a non-Muslim. These stories also widely circulate on the Internet. About 40 websites disseminate the interviews of 'Amal Khodayr with ten 'repentant artists' under the title My journey to the world of Faith.$^{5}$ Like conversion stories, the narratives of repentant artists are part of a worldwide da wah strategy (van Nieuwkerk 2006).

In the genre of the repentance literature, the depth and sincerity of the artists' remorse, and particularly the divine nature of their guidance, was detailed. It was presented as the work of God since He chooses whom to guide and at which moments-whether before or after the earthquake, during the pilgrimage or after dancing and drinking in a nightclub. It was felt that linking their spiritual turn to illness or the earthquake obscured the direct hand of God in the artists' guidance to the right path. For that reason, the visions and moments of spiritual illumination were spelled out in the Islamist press. Several artists, such as Hala al-Safi, Shams al-Barudi and 'Afaf Sho'ib, narrated their dreams, visions and spiritual moments. This pertained to dreams of deceased relatives, the vision of the prophet, the expulsion of the devil and several spiritual experiences during the pilgrimage. It also included descriptions where they felt unable to control their own movements and utterances, such as prayers coming forth without their control or leaving them speechless. Also, being unconscious, hypnotised or in trance were all mental states that pointed at an outside force directing them (van Nieuwkerk 2008).

For the Islamist press and supportive sheikhs such as al-Sha'arawi and Dr. 'Omar 'Abd al-Kafi, the repentant artists could only be new models for pious womanhood if they were totally clean. This meant a moral, mental and material break with their pasts. This raised the issue as to what stepped-down artists should do with the savings from their 'sinful profession'; for, surely, they could not happily live their lives of remorse from the 'sinful money.' They were not even allowed to use it for charity, as the money is haram and God receives only money from a halal source.

\footnotetext{
${ }^{5}$ For instance, Islamna, accessed on January 2004.
} 
Several stepped-down artists asked al-Sha'arawi's advice. During the interview, Hala al-Safi explained to me that Sheikh al-Sha arawi advised her to invest her money in a morally good project. The money she would gain from this project would be halal and she could live off it. She opened an Islamic school.

In accordance with the Islamist representation of the 'return of artists to the right fold' as divinely inspired and beyond doubt, the accusation of payment was depicted as totally false. It proved, however, difficult to counter the accusations of payment except for general statements that guidance is from God and is priceless. The limits of 'obscenity and debasement' were reached for the Islamist author, Magdi Kamil, when the accusation of money paid for divine guidance was launched in the secular press. He felt the need to defend the artists from this immoral campaign which put their true belief in Islam in doubt. He claimed that the campaign was the work of the enemies of Islam: that is, journalists who thrived on artists' scandals and degeneration and feared for their income if the caravan of repentant artists would grow (Kamil 1993: 18-19). In his portraits of the artists, he contrasted the former 'dissolute lifestyle' with the 'total harmony and devotion' of the ex-performers' present life. Art was deemed to debase women's virtue and the return to the home was presented as a bliss (idem: 21). The Islamist press thus used the smearing campaign against repentant artists to slander the scene of art. They defamed the art scene as a corrupt field, particularly for women. They reversed the argument and suggested that it would be good if money could be paid for repentance instead of sinning. Particularly, Sheikh Mitwalli al-Sha arawi was quoted as saying 'if we find someone who wants to pay for divine guidance as others pay for digression, we will thank God' ('Issa 1993: 76).

The ex-performers became powerful new models for pious women. Female artists who veiled and left art for the home were perfect tools for reaching the masses with a message of veiling and domesticity. Sheikh al-Sha'arawi and Dr. 'Omar 'Abd alKafi were known for their conservative views on women and their great stress on domesticity (Abu Lughod 1998; Hatem 1998). They were influential in forging new ideals for Muslim women, images which were powerfully embodied and mediatized by the repentant artists. The Islamist press claimed that it was precisely this Islamic role model for women and the family that the secular press feared most. One author, Yasir Farhat (1993), working for the international association for da 'wah and media, devoted his book to the 'huge complot' going on to destabilise the Muslim Family. He turned the accusations of payment upside down and claimed that the 'enemies of Islam' - the West, Jews, the secularists - paid for slandering repentant artists and made them stay in art. These 'enemies of Islam' knew the importance of women, their virtue and the stability of the family for the Islamic faith. If this pillar were destroyed, Islam would be smashed. They wanted the Muslim women, seen as 'vulnerable and easily influenced', to leave the home, reveal themselves and work in such disreputable fields as art.

The Islamist press thus also invoked a discourse of 'cultural nationalism'. In their version, however, the source of inauthenticity is not Saudi Arabia, but the West, Jews and the enemy from within, the secularists. Besides the competing views on religion and art, there were rivalling views on gender. The conservatives and Islamists projected an image of the 'good pious woman' who veiled, stayed at home and provided care for her house, husband and children. Work outside the home in 
general, but in disreputable fields like art in particular, were singled out as unIslamic. Paid labour in the name of freedom, liberating women by unveiling and leaving the house were seen as the views of 'the enemies of Islam'. The female performer and Muslim woman were depicted as diametrically opposed to each other. The veiled ex-performers bridged the antithesis through their repentance.

\section{Entre act: government control and conservative morality}

The Islamist campaign against art not only used the written stories of repentant artists but also other media. Sheikh Mitwalli al-Sha arawi promoted the repentance of artists through his TV programs. Dr. 'Omar 'Abd al-Kafi produced about 90 tapes in this period mostly dealing with the Day of Judgement. A production company from the Gulf produced a series on 'those who are guided.' 'Afaf Sho 'ib was the first to tell her story. Yet it was banned by the Egyptian censor, Abu Shadi, because he considered it insulting to the performing artists (al-Kawakeb, 17-2-1998). The authors of The Repentant Artists and the Sex Stars claimed that advertising for the book was refused by Egyptian censorship (Nasif and Khodayr 1993: 15).

This brings us to the ambiguous role of the government which tried to restrict the dissemination of Islamist views, but had a confusing and shifting policy. On the one hand, the regime tried to project a modern image and was officially secular. On the other hand, it perceived itself as the moral guardian of the values of society and religion and tried to prove itself more religious than the 'fundamentalists' (Tadros 1994). It tried to encompass the moderate forms of the Islamic revival movement but to undermine the militant or oppositional strands. There was therefore difficulty in drawing clear-cut boundaries between the state and a 'counterpublic'. ${ }^{6}$ Not only conservatives and some strands of the Islamic revival were entangled with the regime, as this also held true for the secular cultural field. Hirschkind (2006) warns against analysing the state as a single entity. It is not a monolithic bloc but comprises of several agents, institutions and individuals influenced by the Islamic revival movement.

As Samia Mehrez (2001) and Jessica Winegar (2006) argue, the regime and the secular cultural field are closely related. The state has produced modern cultural institutions. These institutions are dependent on the government for their effectiveness and have become the protégé of the state. Yet, the state also depends on the cultural players to articulate its semblance of modernity to the world (Mehrez 2001: 10-15). This does not preclude criticism by secular artists, producers and journalists on the regime, yet they collide in their defence against an 'Islamisation of the cultural sphere'. The interdependency between the state and the cultural field makes it likely to assume that the above-mentioned campaigns against Islamists and the repentant artists were approved by the state.

\footnotetext{
${ }^{6}$ Hirschkind (2006: 106, 232) does not use the notion counterpublic in the sense of Fraser (1990), that is referring to the discursive arenas of subordinate and oppositional groups, but uses it to distinguish the different sensorium underlying the discursive practices of the contestory movement from the liberaldemocratic understandings. In this section, I will follow Fraser's original use of the term counterpublic and come back to Hirschkind in the epilogue.
} 
One obvious example of the state's 'modernity policy' was banning the veil. During the period of armed conflict with militant Islamists, the government began to see the Islamic dress as a political symbol and a threat. Veiled women were banned from the media as well as from the state and private educational institutions. The policy was eventually concretised in the controversial Unification of School Uniform Order in 1994 that forbade schoolgirls from wearing hijab (Herrara 2001: 16-19). Several stepped-down artists were forced to retire because the regime did not allow them to work as veiled actresses or TV presenters. Kamilia al- Arabi for instance wanted to resume her work as a TV presenter of a religious program but was mocked and fired (Hiwar, 6-9-2001). So the anti-veil policy of the regime hindered the return of the stepped-down actresses in the early 1990s. Those who wanted to work as veiled actresses were forced to work for foreign, Saudi, channels or productions aimed at that market (Tartoussieh 2007). One of the few examples of a veiled TV presenter was the hostess Kariman Hamza (Malti-Douglas 2001). She was allowed to present a religious program during Ramadan 1993 in which she invited Dr. 'Omar 'Abd al-Kafi to explain his conservative views. Also, Mustafa Mahmud and Sheikh Mitwalli al-Sha arawi were given ample media space in the 1980s to spread their brand of Islamic thought.

Hirschkind (2006) noted the shifting policies of the state towards the diverse strands of the Islamic revival movement. He distinguished official khutaba preachers, promoted by the state, from the non-official or oppositional da iyat preacher belonging to the Islamic Revival movements. But he also acknowledged that several preachers of the 'counterpublic' such as Kishk also preached at state mosques. The government tried to exercise increasing control over mosques and sermons. Through the institution of $d a$ 'wah institutes, certifying future preachers, they also tried to influence the Islamic discourse. Sheikh al-Sha'arawi was critical of the government but was allowed to voice his opinion from within the state's institutions. Dr. 'Omar 'Abd al-Kafi was initially allowed to appear on TV until he was muzzled because his preaching was considered to be too militant. His tapes were, however, broadly consumed in the contestory Islamic revival movement. Depending on the states' appraisal of the danger of individual preachers, they were allowed media space or were banned and forced to use the less controlled public sphere of tapes.

The amount of religious programming was generally expanding during this period. Besides outlawing criticism of religion and erosion of national unity, many stipulations of the latest 1976 censorship law were connected to morality, such as forbidding justification of immoral actions, images of naked bodies, emphasis on erotic parts, sexually arousing scenes and disrespect for the sanctity of family values (Shafik 2001a). Arising from the dependency of the cultural field on the state, self censorship was strong. Besides, as Abu Shadi (1994), the current artistic censor, noted, during the 1980s and early 1990s the censors were Islamic conservatives themselves. 'Extremist religious' influences had been allowed to infiltrate television programs and artistic compositions. Coupled with the growing influence and space allowed to censorship by al-Azhar-leading to the statement that al-Azhar is the authority to which the Ministry of Culture must approve licenses for films, books and tapes that discuss religion-the twisted position of the regime became clear (Abu Shadi 1994; Engel 2004). 
Another factor conducive for the morally conservative programming was the influence of Saudi Arabia on the cultural field in Egypt. The investments of money from Saudi Arabia in the Egyptian art industry led to censorship and production in accordance with Wahhabi Islam (Ramzi 1994). Since movie theatres were not allowed in Saudi Arabia, it was particularly with the introduction of the VCR that a market for home videos was opened up. The Gulf States became the main customers during this period and were thus able to enforce their censorship regulations. With the petrodollars, prudishness moved in, as Viola Shafik (2001b) aptly remarked. It is only after the mid-1990s that the government and the cultural field started to use the media to discredit 'fundamentalists'. They even used the genre of repentance narratives by broadcasting a 'repentant extremist' who turned to the 'right' - in the view of the regime-religious fold on TV.

\section{Fourth act: ambivalent responses by stepped-down actresses}

Islamists harshly judged the artists' past and depicted them as sinners. Only by being born again could they start pious and clean lives as wives and mothers. Some repentant artists shared this view, others had more nuanced views on their past activities and art in general. The fierce attacks by the secular press drove them into the arms of the Islamist press. The Islamist embrace was comforting but perhaps too warm and eager. The responses of the 'repentant artists' to the commotion they have caused were diverse.

Shams al-Barudi was harassed by the continuous programming of her old films. She eventually felt forced to publish an announcement in several newspapers because she feared people might think that she resumed acting. She declared that she stepped down from art since February 1982 and that they were showing old films (Ittahad, 8-8-1985). All ex-performers reacted vehemently against the accusations of payment. They mentioned several arguments as to why it was illogical to assume payment for veiling. If artists were after money they would have kept on working. Besides, as they earned a huge amount of money as artists, who could pay such a high salary for many years to so many artists? And what about all other veiled women, the doctors, engineers, teachers, medical doctors? Were they all paid for veiling, they rhetorically asked. Dancer Hala al-Safi snapped that no one would ever pay for veiling, only for revealing. Other actresses reversed the argument and mentioned that they were offered money for resuming acting and unveiling. In a collective letter, they stressed that they left the thousands and millions of pounds while they were still in their youth. They left the life of beauty and cheap enjoyments to devote themselves to God and paradise. They wished the slanderous press the same divine guidance as had befallen them (Kolenas, 9-9-1992).

They were particularly stung by Nagwa Ibrahim's story of groups paying large amounts of money and sent an open letter to several newspapers. Signed by 12 stepped-down artists they wrote a statement that if it was really true that groups secretly paid money, it was a dangerous development for the nation. It was therefore Nagwa Ibrahim's duty as a citizen to protect the country and to bring forth the names of those who offered payment (Mawed, 1-10-1992). The names were never released. They thus played the card of vigilant citizens. In individual reactions, they 
particularly emphasised that God's guidance had no equivalence in money and that no material gain was comparable to the 'taste of the sweetness of faith and obedience'.

The stepped-down artists thus rubbed along with the Islamic press. Yet not all of them had such gloomy views about their past activities and about art in general. Especially in response to the secularist press' discrediting of their talents, they felt challenged to claim their successful careers. This claim was ill at ease with the concept of repentance. The complexity of their positioning between the secularist debunking of their talents and the Islamist discourse of repentance was revealed to me during an interview with Hala al-Safi. I expected it would be difficult to touch on her former work as a dancer in nightclubs. Yet without hesitation she told me about the novelty of her former shows and the high level of her art. She described herself as an ambassador for Egypt as she used to be invited to perform at many parties outside Egypt. At the end of the interview in which she recounted her vision of the prophet who covered her nakedness, I asked if she had only a feeling of regret about her work or was also proud about her past performances. She then answered that regret was a necessary part of repentance and that of course she could not be proud about her past as this would question her sincere remorse.

Several artists thus felt insulted by the suggestion that they were less in demand, of mediocre level and growing old, and accordingly stressed their youth and talents. For most of them, this heightened the extent of God's guidance. If you could leave stardom, wealth and the spotlights for God, something very forceful must have happened in your life. Whereas most emphasised divine guidance as central in their story, not all used repentance as a concept to describe their religious turn. Divine guidance was not necessarily linked to 'repentance'. Several positions were discernable towards the notion of 'toba', 'repentance'. Some of them, like Hala al-Safi and Shams al-Barudi, used the concept to signal a total break with the life before. Art was likened to the devil which was removed from their lives. Hala al-Safi's exclamation 'the devil has stolen my life', or the story of Shams al-Barudi in which the devil was expelled from her body, were striking examples confirming the image of a total rupture of a life 'before and after'. They did not mind being called repentant artists. They regretted their former activities and considered art haram and 'of the devil', or at least for women.

Other artists, like Yasmin al-Khiyyam and Hoda Sultan, strongly detested the concept of 'repentance'. Yasmin al-Khiyyam refused to cooperate with Nasif and Khodayr's second edition of their book. She was insulted by the title of the first edition of Repentant Artists and the Sex Stars. She forecast that they would enter 'hell' (Nasif and Khodyar 1993: 93). She did not consider her former career as a singer of mostly religious and national songs sinful. She quit because she became very much involved with the charity organisation of her late father, Sheikh al-Hosari (personal interview, 3 March 2005). Also, Hoda Sultan rejected the term repentance when she decided to act veiled (Al-Liwa' al 'Islamiyya, 6-5-2003). She was totally convinced of art and its potential to raise the awareness of people. She saw no reason to step down and not to use her god-given talent as an actress.

A third position among artists was taken by those who did not mind the concept 'toba', but used it in a more subtle and generalised way. They pointed at the habit of the prophet to repent 70 times a day. All people make mistakes and commit sins and 
it is lofty practice for anyone to repent. This did not necessarily mean that they considered art haram. They might dislike most art in its present form for its low, cheap and un-Islamic character but were convinced that art 'can have a mission'. This line of thought became more prominent after the mid-1990s when several of them returned to the screen.

Artists' (dis)like of the label repentance was thus directly connected to their views on art's permissibility. Several of the stepped-down artists of the 1980s, such as Shams al-Barudi, Hana' Tharwat and Hala al-'Safi, strongly argued for its unlawful nature, particularly for women. Most artists who stepped down in the early 1990s were more ambivalent in their views or changed their ideas on art in the course of time. For instance, Soheir al-Babli did not deny art's potential as a messenger. Several artists like 'Afaf Sho' ib initially stated that art is haram but transformed their ideas within years to the conviction that art can have a purpose if it is done within an Islamic framework. After an initial stage of rather conservative views, they turned to a more moderate discourse on art and gender. 'Abir Sharqawi, who replaced Soheir al-Babli in the play her father directed, stepped down herself seven years later. During the interview in 2005, she told me that she was initially quite strict in her views due to the influence of preachers such as Dr. 'Omar 'Abd al-Kafi and the repentant artists who had turned into preachers. But after dissociating herself from the community of stepped-down artists and reading for herself, she came to a new understanding of art. During the late 1980s and early 1990s, though, a rather conservative discourse on art and gender dominated the community of stepped-down artists.

Conservative and Islamist preachers, such as Sheikh Mitwalli al-Sha arawi and Dr. 'Omar 'Abd al-Kafi, were clearly influential in the artists' choices to leave art and veil. The Islamist press used their stories as a golden opportunity to defame art and promote their views on gender. Yet, stepped-down artists were seemingly not only passive pawns of the Islamist agenda. Shams al-Barudi was actively engaged in da'wah, mainly among her relatives and friends, including artists. Hana' Tharwat and Kamilia al-'Arabi turned into preachers, da iyat, lecturing at houses for women of the middle and upper-middle class (Ruz al-Yusif, 1-3-1993). They were influential in the emergence of the phenomenon of the 'Islamic salons' (Haenni 2002; van Nieuwkerk 2008). 'Afaf Sho'ib was proud of her da'wah activities. Yasmin alKhiyyam turned into an influential personality through her position as the director of the charity organisation cum mosque al-Hosari. She gave the floor to new preachers, such as Dr. 'Omar 'Abd al-Kafi in the early 1990s, and later on to 'Amr Khaled. Several repentant artists entered da wah institutes and preached in private; some of them were eventually able to return to the screen and host religious programs. They were mostly banned from the Egyptian TV channels and worked on foreign channels.

All of them strongly advocated and publicised the veil. Women's veiling was seen as of primary importance and the final step to iltizam, that is, to become observant pious Muslim women. Preachers like Sheikh al-Sha'arawi and Dr. 'Omar 'Abd al-Kafi made them aware that veiling is 'obligatory' and a 'commandment from God' just like fasting and praying. They were not aware of its obligatory character and centrality for pious Muslims. Doing charity, praying, and fasting and going to Mecca were in their view the quintessential conditions for piety. Yet through these preachers they became aware that veiling was a condition just as important for pious womanhood as the uncontested pillars of Islam. Putting veiling on the same footing 
as the recognised pillars of Islam was according to its secular and moderate Muslim critics a clear indication of the Saudi-tisation of their Islam.

Whereas they all advocated the veil, not all stepped-down artists completely shared the preachers' ideals of womanhood and domesticity. The ex-performers/ preachers, such as Shams al-Barudi, Kamilia al-'Arabi and Hana' Tharwat, shared Sheikh al-Sha`arawi's and Dr. 'Omar `Abd al-Kafi's notions on gender and domesticity. Shams al-Barudi, for instance, considered motherhood a divine task that suits the female nature. Women are created to be mothers, not to be engineers or farmers. But if they fulfilled the tasks of motherhood adequately they are allowed to work within the confines of the religious commandments. Women should not work if this results in the neglect of children and only if it is a matter of sheer necessity. Those women who leave their children in a kindergarten are not acting according to Islam (van Nieuwkerk 2008). Yet, the ex-performers themselves did not necessarily practise these ideals.

The pious ex-performers have remained important public figures. Several worked as preachers, or were engaged in Islamic charity, such as Kamilia al-'Arabi, Hana' Tharwat, Shams al-Barudi, and Yasmin al Khiyyam. Others started an Islamic business, such as fashion, video or cassette firms. Also, Islamic education and da wah were new fields in which they had entered. Some eventually returned as veiled actresses or hostesses. Afaf Sho 'ib initially lived off her mother's inheritance but returned as a veiled actress. Farida Seif al-Nasr tried some commercial projects but failed and returned to art. She was one of the few who returned unveiled (Ruz al-Yusif, 2-8-1993). Most of them performed veiled and were influential in making veiling fashionable. Many returned out of conviction with the idea of producing clean cinema (al-sinima al-nadifa) or purposeful art (al-fann al-hadif), a trend which has become significant after the mid-1990s. ${ }^{7}$

The first group of stepped-down performers has remained active in public life through preaching in homes and mosques. The veiled actresses of the beginnings of the 1990s eventually returned to the screen and some of them have a religious program such as Shahira, Mona 'Abd al-Ghani and Miyar al-Bablawi. They all sought ways to combine an active public presence with piety and used their (mediatised) presence to publicise their ideas of pious womanhood. For all of them, it held true that they remained influential public figures and influenced the concepts of piety for women. They were working out new models for active pious womanhood in which they combined veiling with public influence and visibility/audibility.

\section{Epilogue: 'repentant' artists and the public sphere}

In this article, I have tried to analyse whether the debates about the repentant artists have lived up to scholars' expectations about the role of new media in the emergent public sphere in the Middle East. The repentance of artists is an interesting case for

\footnotetext{
${ }^{7}$ This trend of returning to art, fashionable veiling and the production of pious art is very interesting and needs more space than is allowed within the context of this paper. I am preparing a presentation on this issue: 'New Religiosity and 'Fann al-Hadif' 'Art with a Mission' in Egypt. ESF Exploratory Workshop 'Islamization of the cultural sphere? Critical perspectives on Islam and performing arts in Western Europe and the Middle East', 23-24 October 2008, Amsterdam.
} 
analysing the public sphere in Egypt. First, this issue forms a delicate matter because the artists left the world of secular art for that of piety. For that reason, they have been tremendously important in starting the debate about Islam and art. Second, it is also a good example for analysing the use of media in the public sphere because these former performers are public figures with a high media profile. All parties involved realise the enormous influence of their repentance and veiling on millions. All voices extensively use the media in order to pull a massive public over to their side.

Habermas expected the religious to retreat from the public sphere into the private sphere in the West, an assumption criticised by Salvatore and Eickelmann (2004) for the Middle East. We have indeed seen that Islam is the dominant framework for discussing notions of the 'common good'. The regime, Islamists, conservative Muslims, liberals and secularists all framed their ideas about art, gender and cultural authenticity in religious terms. Instead of retreating, it could be argued that the religious framework has extended its scope into the debates about such issues as art and culture, a sphere which is often considered the last stronghold of secularism. Religious notions entered the 'cultural public sphere' in the sense that it framed the deliberations on art and culture. Whereas in the early 1990s the Islamist discourse was predominately against art, these discussions paved the way for new ideas which were to sprout after the mid-1990s. The ensuing discourses about proper Islamic art, 'pious art' or 'art with a mission' evolved from the increasing enmeshment of Islamists within the 'cultural public sphere'.

A second expectation is that the new media would give the opportunity for new voices to enter the debate and, more importantly, that these new voices could be regarded as a counterpublic. Within the authoritarian climate of Egypt, an implicit assumption is that these new counterpublics will be of a more democratic or antiauthoritarian kind. We have seen that the new media is extensively used and that new members entered the public arena, in this case foremost the repentant artists. Yet as to the question of whether the oppositional voices form a counterpublic the answer is less clear. Several problems have appeared. First, in this extremely tense period in which terrorist attacks and a harsh knocking down of Islamist opposition by the regime flushed over the country, the formation of publics is a contested process itself. Second, the notion of a counterpublic is not easy to hold in the Egyptian context.

Repentant artists were merged with the 'Islamists', which in turn were amalgamated with the 'extremists' in the campaign of secularists and the regime. Secularists, performing artists and the regime were combined as 'the enemies of Islam' in the Islamist press. The multiplicity of voices was dissolved into two competing blocs. While there appear to be two clear-cut parties involved in the discursive arena, this is misleading. The regime is not a monolithic agent and includes several fractions of Islamists as well. Secularists are dependent and entangled with the regime but the same holds true for several fractions of the Islamic revival movement. The stepped-down artists were crushed between the opposite voices but were also internally divided.

The whole idea of an independent oppositional counterpublic thus appears difficult to maintain in Egypt due to the encompassing character of the state. Yet this does not necessarily foreclose contestory movements and ideas. In that sense, Hirschkind's (2006) idea of counterpublic is interesting. He analyses the Islamic revivalist movement or $d a{ }^{\text {' }}$ wah movement as a counterpublic. He does not use the notion of Fraser (1990) in the sense that the counterpublic is autonomous and 
sovereign with respect to the state. In his study of the Islamic cassette media, Hirschkind shows that this Islamic soundscape combines ethical exercise, political debate and popular entertainment. It is a form of political contestation and cultivation of religious sensibilities and affect that creates a separate moral space. Building on Asad's insight that the public sphere is not an empty space but is constituted by the sensibilities of participants, he analyses the role of audition in crafting public sensibilities. He thus shifts the attention from Habermas' ideas of political deliberation as a rational disembodied form of reasoning to the ethical values and religious sensibilities and affect for social and political life (idem: 3031). Hirschkind thus rather emphasises the different sensorium and moral dispositions underlying the discursive practices of the oppositional $d a$ wah movement as forming an ethical counterworld rather than the independent character or content of their deliberations (Hirschkind 2006: 105-143).

Hirschkind particularly elaborates his arguments with regard to the auralpreaching or speaking and listening or audition - and concentrates on cassette sermons as the medium for contestation. This is contrasted with the visual scape and print. The repentant artists are mainly connected to TV and print, the media mostly used and controlled by the government. Some of them became presenters of religious programmes or TV da iyat. Those who preached at private homes as da iyat did not produce tapes as far as I know. Yet visibility and audibility are not always easily separated with regard to preaching. Also, the more general argument of situating contestation in the public sphere beyond rational disembodied forms of reasoning by autonomous groups or individuals is stimulating. This is accordingly an intriguing approach to follow up with regard to the pious art productions that were to emerge after the mid-1990s.

Finally, what about the 'new ideas' of the repentant artists? As women, they were certainly new voices in the public deliberations on Islam and art, but how far did they express new ideas? They were not passive pawns of the Islamists' agenda. They were willing partners for at least a part of the Islamists' notions of the pious woman. Particularly with regard to the importance of veiling, the views of the veiled artists and Islamists collided. They actively used their public prominence to promote veiling among women. They have eventually helped to make veiling fashionable, a trend not yet very visible in the early 1990s. With regard to art and gender, a mixed picture emerged. Although in the early 1990s conservative views on art and gender prevailed, not all former performers shared this view. Even if they upheld ideas on the centrality of women's domesticity and the Muslim family they did not live up to this ideal in their personal lives. They remained important public personalities, as preachers, business women in Islamic businesses or in charity. With regard to art, there was an ambivalence too: they did not all distance themselves from their art productions and several of them eventually returned. They have thus been influential in setting off the debate on Islam and art and eventually in the creation of new forms of pious art. They have thus been important in the emergence of a pious cultural sphere. Yet this materialised only after the mid-1990s when the climate in Egypt became less tense.

Open Access This article is distributed under the terms of the Creative Commons Attribution Noncommercial License which permits any noncommercial use, distribution, and reproduction in any medium, provided the original author(s) and source are credited. 


\section{References}

Abaza, M. (2006). Changing consumer cultures of modern Egypt, Cairo's urban reshaping. Leiden: Brill. Abu Lughod, L. (1998). The marriage of feminism and Islamism in Egypt: selective repudiation as a dynamic of postcolonial cultural politics. In L. Abu Lughod (Ed.), Remaking women (pp. 243-270). Princeton: Princeton University Press.

Abu Shadi, A. (1994). The Influence of terrorism and extremism on official governmental censorship over the cinema and television in Egypt. Resource Document. http://www.geocities.com/CapitalHill/ Lobby/9012/Fredom/shadimain.htm. Accessed 18 November 1999.

Brooks, G. (1998). De dochters van Allah. Amsterdam: Ooievaar.

Eickelman, D. F., \& Anderson, J. W. (1999). Redefining Muslim publics. In D. F. Eickelman, \& J. W. Anderson (Eds.), New media in the Muslim world. The Emerging public sphere. Bloomington: Indiana University Press.

Engel, R. (2004). Book ban exposes Azhar censorship. Middle East Times, 10 November 2004. Resource Document. http://www.metimes.com. Accessed 5 November 2006.

Farhat, Y. (1993). Mu 'araka al-hijab. Israr wara' al-hijab al-madfu'. Cairo: Dar al-Rawada.

Fraser, N. (1990). Rethinking the public sphere: a contribution to the critique of actually existing democracy. Social Text, 25/26, 56-80.

Haenni, P. (2002). Au-delà du repli identitaire. Les nouveaux prêcheurs égyptiens et la modernisation paradoxale de l'islam, Religioscope novembre 2002. Resource Document. www.religioscope.com. Accessed 20 May 2005.

Hatem, M. (1998). Secularist and Islamist discourses on modernity in Egypt and the evolution of the postcolonial nation-state. In Y. Yazbeck Haddad, \& J. Esposito (Eds.), Islam, gender \& social change (pp. 85-100). Oxford: Oxford University Press.

Herrara, L. (2001). Downveiling. Gender and the contest over culture in Cairo. Merip, 219, 16-19.

Hirschkind, C. (2006). The ethical soundscape: cassette sermons and Islamic counterpublics. Columbia: Columbia University Press.

'Issa, I. (1993). al-Harb bi al-niqab. Cairo: Dar al-Shabab.

Kamil, M. (1993/1994). Fannanat wara al-hijab. Cairo: Markaz al-Raya li al-nashr wa al-tawzi'.

Mahmood, S. (2005). Politics of piety. The Islamic revival and the feminist subject. Princeton: Princeton University Press.

Malti-Douglas, F. (2001). Medicines of the soul: female bodies and sacred geographies in a transnational Islam. Berkeley: University of California Press.

Mehrez, S. (2001). Take them out of the ball game. Egypt's cultural players in crisis. Merip, 219, 10-15.

Nasif, I., \& Khodayr, A. (1993). Fannanat ta `ibat. Cairo: no publisher.

Ramzi, K. (1994). From extremism to terrorism: the relationship between religious groups and the arts. Resource document. http://www.geocities.comCapitolHill/Lobby/9012/Freedom/kintroduction.htm. Accessed 18 November 1999.

Salvatore, A., \& Eickelman, D. F. (2004). Preface. In A. Salvatore, \& D. F. Eickelman (Eds.), Public Islam and the common good (pp. xi-xxiii). Leiden: Brill.

Shafik, V. (2001a). Egyptian cinema. Companion encyclopedia of Middle Eastern and North African film pp. 23-130. London \& New York: Routledge.

Shafik, V. (2001b). Prostitute for a good reason: stars and morality in Egypt. Women's Studies International Forum, 24(6), 711-725.

Tadros, M. (1994). Women: the perspectives of fundamentalist discourse and its influence on Egyptian artistic creativity and cultural life. Resource document. http://www.geocities/CapitolHill/Lobby/9012/ Freedom/marlynmain.htm. Accessed 18 November 1999.

Tartoussieh, K. (2007). Pious stardom: cinema and the Islamic revival in Egypt. Arab Studies Journal, 17 (1), 30-44.

van Nieuwkerk, K. (2006). Gender, conversion, and Islam: a comparison of online and offline conversion narratives. In K. van Nieuwkerk (Ed.), Women embracing Islam, gender and conversion in the West (pp. 95-120). Austin: Texas University Press.

van Nieuwkerk, K. (2008). Piety, repentance and gender: born-again singers, dancers and actresses in Egypt. Journal for Islamic Studies, 28, 37-66.

Winegar, J. (2006). Creative reckoning. The politics of art and culture in contemporary Egypt. Stanford: Stanford University Press.

Zubaida, S. (2002). Religious authority and public life. ISIM Newsletter, 11, 19. 